\title{
Bird communities and vegetation composition in Nusa Penida, Bali, Indonesia
}

\author{
FRANCISCUS XAVERIUS SUDARYANTO ${ }^{1}$, JUNITA HARDINI ${ }^{1}$, LALU ACHMAD TAN TILAR \\ WANGSAJATI SUKMARING KALIH ${ }^{2}$, MUHAMMAD MIRZAN ASRORI ${ }^{3}$, I WAYAN SUANA ${ }^{3, \vee}$ \\ ${ }^{1}$ Department of Biology, Faculty of Mathematics and Natural Sciences, Universitas Udayana. Jl. Raya Kampus Unud No. 9, Jimbaran, Badung 80361, \\ Bali, Bali, Indonesia \\ ${ }^{2}$ Department of Fisheries Resources Utilization, Faculty of Fisheries, Universitas 45 Mataram. J1. Imam Bonjol, Mataram 83239, Nusa Tenggara Barat, \\ Indonesia \\ ${ }^{3}$ Department of Biology, Faculty of Mathematics and Natural Sciences, Universitas Mataram. Jl. Majapahit No. 62, Mataram 83126, Nusa Tenggara \\ Barat, Indonesia. Tel.: +62-370-646506, `email: wynsuana@unram.ac.id
}

Manuscript received: 31 August 2019. Revision accepted: 23 November 2019.

\begin{abstract}
Sudaryanto FX, Hardini J, Kalih LATTWS, Asrori MM, Suana IW. 2019. Bird communities and vegetation composition in Nusa Penida, Bali, Indonesia. Biodiversitas 20:3676-3683. A study on bird community and vegetation composition in Nusa Penida was carried out to determine its diversity, conservation status, and habitat as an effort to conserve and develop birdwatching ecotourism in Nusa Penida. The study was conducted in Tembeling forest and Ped agroforestry. By using the point count method, we found 80 species of birds: 70 species in Tembeling forest and 79 species in Ped agroforestry. Fourteen species of birds are protected by Indonesian law. According to the IUCN Red List of Threatened Species, four species are Critically Endangered and one species is classified as Near Threatened. We also found eight species of migratory birds. Diversity of birds in Nusa Penida was high. Individuals of each bird species was spread evenly, except Hirundo rustica, Hirundo tahitica and Streptopelia chinensis were dominant. Twenty-five species of trees were found in Tembeling, while in Ped were found 22 species. These vegetations were provided birds with good resources for foraging, resting, and nesting.
\end{abstract}

Keywords: Awig-awig, bird conservation, birdwatching ecotourism, migratory birds

\section{INTRODUCTION}

Bali has a diverse landscape with its highest peak is Gunung Agung, 3,142 meters above sea level. Between the tallest mountain and the sea-sand areas, there are forests, flowing rivers, alluvial slopes and green rugs of crop fields. The forests of Bali stretch on the north western part of the island. The Bali Barat National Park is established to preserve the forests and their wildlife. Bali Starling Leucopsar rothschildi is an endemic bird of Bali found in this park. Besides Bali Starling which is the mascot of the Province of Bali, there are also 344 species of birds on this island, of which 190 are considered residents, 83 as regular visitors and 71 as vagrants (Mason 2011). One additional species, Greater Painted Snipe Rostratula benghalensis, is a new record for Bali that has not been recorded in Mason's checklist (Hermawan et al. 2013).

Nusa Penida is a small island located $20 \mathrm{~km}$ to the southeast of Bali. It has a limestone mountain with wooded grassland soil types whose water availability is very poor (Riany and Aunurohim 2013). Based on the Schmidt and Ferguson climate classification, Nusa Penida has an E climate type, with an average rainfall of $972 \mathrm{~mm} /$ year, and an average of 5.58 rainy days. The area of Nusa Penida is 20,284 ha, consisting of 1,000 ha of forest, most of which is agroforestry. The length of the coastline is $83.50 \mathrm{~km}$ (Pemkab Klungkung 2013). Nusa Penida is an ex-situ conservation area for Bali Starling recommended by Friends of National Parks Foundation (FNPF), a local NGO of Bali. It was chosen as the center for rescue and release of Bali Starling because it has forest areas, agroforestry, and grasslands that can support the life of Bali Starling (Wirayudha 2008). In addition, community participation with its awig-awig (Balinese Common Law) has succeeded in protecting the existence of Bali Starling in Nusa Penida (Sudaryanto 2019). This is interesting for tourists to come to Nusa Penida (Agustina 2013). In 2018 the number of tourists who came to Nusa Penida was 350,000 people, and $80 \%$ are foreign tourists (Sudiarkajaya et al. 2018).

Habitat conditions generally have an effect on bird abundance and diversity (Partasasmita et al. 2017; Krisanti et al. 2017). To support the life of birds, it is necessary to have a single unit of habitat that can guarantee all the necessities of birdlife, such as food, resting and nesting places. We report here the bird diversity, conservation status, and bird habitat in Tembeling forest and Ped agroforestry as an effort to conserve and develop birdwatching ecotourism in Nusa Penida.

\section{MATERIALS AND METHODS}

\section{Study area}

The study lasted for three months (January to March 2019) in Tembeling forest and Ped agroforestry, Nusa Penida, Bali, Indonesia (Figure 1). Tembeling forest is located at an altitude of 200 to 250 meters above sea level (masl), and Ped agroforestry at an altitude of 0 to $130 \mathrm{~m}$ 
asl. Agroforestry is a plantation that integrates timber tree management with commodity crops (van Noordwijk et al. 2004; Wulandari 2009). Large trees, such as Syzygium cumini, Ficus benjamina, and Azadirachta indica can be found in Ped agroforestry. In addition to these trees, there are coconut palms, cassava, corn, nuts, bushes, grasslands, and settlements (Ginantra et al. 2009). Tembeling forest is a natural forest that stores a lot of water on its soil favoring the growth of ferns or the like. Several species of large trees, including Ficus glabella, Ficus benjamina, Acacia auriculiformis, and Lannea grandis grow in this forest (Riany and Aunurohim 2013; Sudaryanto et al. 2015).

\section{Sampling procedure}

Bird sampling was carried out using point count method (Bibby et al. 2000). Observations were made from 06:00hr to $11: 00 \mathrm{hr}$, and from $15: 00 \mathrm{hr}$ to $18: 00 \mathrm{hr}$, from January to March 2019. The number of points at each study site was 10, with $100 \mathrm{~m}$ distance between two points in Tembeling forest, and $200 \mathrm{~m}$ in Ped agroforestry. We made a difference in the distance between points at the two study sites because there were differences in the conditions of the study area, where in the Tembeling forest it had a slope of between $40 \%$ to $60 \%$, while in Ped agroforestry was flat. Radius of observation in each point was $30 \mathrm{~m}$, with an observation time of 15 minutes. During the study, it was 10 times visit for each point. Data recorded includes the bird species, the number of individuals of each bird species, and the activity of birds in the strata of canopy. Only birds that perch on the tree are recorded. Activity of birds on the tree was observed by scan sampling method with interval of 5 minutes (Martin and Bateson 2006). Identification of bird species was based on Mason and Jarvis (1994), MacKinnon et al. (2010) and Mason 2011.

To determine the habitat condition, vegetation analysis and habitat profile were made. We used a $20 \mathrm{~m}$ x $20 \mathrm{~m}$ quadrat plot to do vegetation sampling (Barbour et al.
1987). On each quadrat plot, we were record and measure: number of individuals of each species, the total of tree height, the first branch height, canopy width, canopy length, canopy thick, tree diameter at breast height of researcher, the position of the tree (the distance to the $\mathrm{x}$ and $y$ axis), then the vegetation profile is made. The conservation status of birds was based on Regulation of Ministry of Environment and Forestry (Permen LHK) Republic of Indonesia Number P.106/MENLHK/SETJEN/KUM.1/12/2018 of 2018, and International Union for Conservation of Nature's Red List of Threatened Species.

\section{Data analysis}

Diversity of bird and plant was performed using Shannon-Wiener Diversity Index $\left(\mathrm{H}^{\prime}\right)$ : $\mathrm{H}^{\prime}=-\sum_{i=1}^{s} p i \ln p i$, where ' $p i$ ' is proportional abundance. If $\mathrm{H}$ '<1.5 the diversity is categorized as low, values of 1.5 to 3.5 are categorized as moderate, and values> 3.5 indicate high diversity (Magurran 1988).

Distribution of birds in their habitat was determined using Index of Evenness $(E)$ : $E=H^{\prime} / l n S$, where ' $S$ ' is the total number of species in the samples. When ' $E$ ' approaches 0 (zero), the species of bird is not too diverse, and there is dominance of certain species. On the contrary, when 'E' approaches 1 (one), the number of individuals among species is not too different, and there is no dominance of certain species (Ludwig and Reynolds 1988).

Dominance of bird species in each study site, was calculated using the formula: $\mathrm{Di}=(\mathrm{ni} / \mathrm{N}) \times 100 \%$, where 'ni' is the number of individual species-i, and ' $N$ ' is the total number of individuals. Criteria for determining the level of dominance are as follows: $\mathrm{Di}=0$ to $2 \%$ indicated nondominant species, 2 to $5 \%$ showed sub-dominant species, and $>5 \%$ was categorized as dominant species (Dewi et al. 2007).
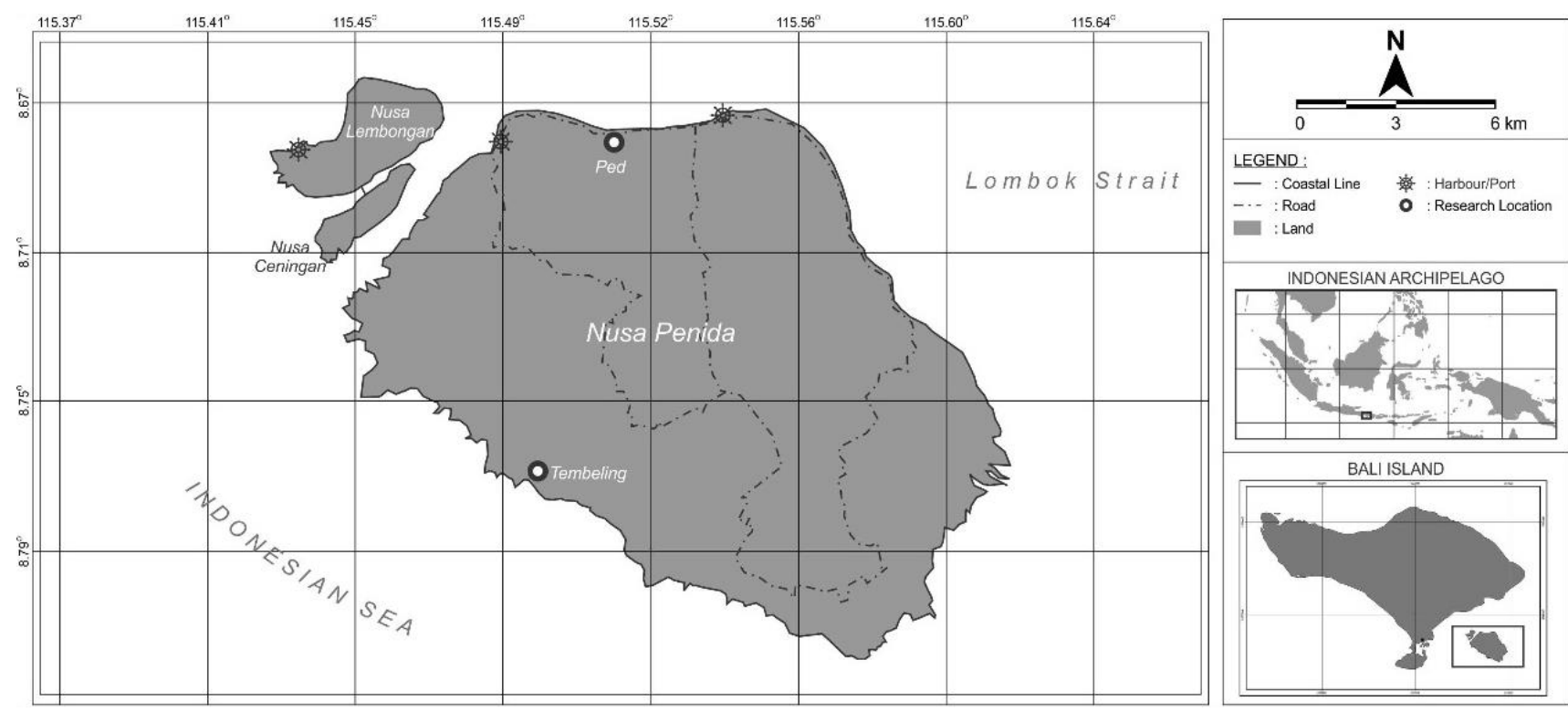

Figure 1. Map showing locations of two study sites, Tembeling forest and Ped agroforestry, Nusa Penida, Bali, Indonesia 
Similarities of bird and plant communities in the two study sites were calculated using the Similarity Index (SI): $\mathrm{SI}=2 \mathrm{~J} /(\mathrm{a}+\mathrm{b})$, where ' $\mathrm{J}$ ' is the number of species that exist in both study sites, ' $a$ ' is the number of species at study site ' $a$ ', and ' $b$ ' is the number of species at study site ' $b$ '. SI less than $50 \%$ indicated low similarity between two habitats, $50 \%$ to $75 \%$ showed moderate, and more than $75 \%$ was categorized high (Setiadi 2004).

The use of habitat $(\mathrm{Ft})$ by birds to perform various activities, such as foraging, perching/resting, and nesting was calculated with the formula: $\mathrm{Ft}=(\mathrm{St} / \mathrm{Sp}) \times 100 \%$, where 'St' is the number of bird species that use habitat or vegetation, 'Sp' is the total number of bird species present at the study site (Dewi et al. 2007; Paskal et al. 2015).

Analysis of the importance of trees in Tembeling forest and Ped agroforestry using an Index of Importance Value (IIV): IIV = RDi + RFi + RCi. RDi (Relative Density) is a comparison between the number of individuals of species- $i$ $(\mathrm{Ni})$ and the number of all individuals $(\Sigma \mathrm{N})$. RFi (Relative Frequency) is a comparison between frequency of species-i $(\mathrm{Fi})$ and total frequency of all species $(\Sigma \mathrm{F})$. RCi (Relative Cover) is a comparison between the area of species-i cover area $(\mathrm{Ci})$ and the total coverage area for all species $(\Sigma \mathrm{C})$ (English et al. 1994).

\section{RESULTS AND DISCUSSION}

\section{Diversity of birds}

During the study, we found 1,185 individuals of birds from 39 families, 61 genera and 80 species (Table 1). In Tembeling forest there were 36 families, 56 genera and 70 species, while in Ped agroforestry we found 38 families, 60 genera and 79 species. Among these species of birds, 14 species are protected by Permen LHK Republic of Indonesia No. P.106/MENLHK/SETJEN/KUM.1/12/2018 of 2018, and 66 species not protected. Based on IUCN Red List of Threatened Species, 1 species (Numenius arquata) is catagorized as Near Threatened, 4 species (Cacatua sulphurea, Fregata andrewsi, Acridotheres tertius, and Leucopsar rothschildi) as Critically Endangered, and 75 species of Least Concern.
Bird diversity $\left(\mathrm{H}^{\prime}\right)$ in Tembeling forest was 3.75 , with an Evenness Index (E) of 0.89. This means that the diversity of bird species was high. The number of individuals of each bird species was not too different, although there were some dominant bird species (Table 1), such as Hirundo rustica $(\mathrm{Di}=6.20)$, Streptopelia chinensis (Di = 5.60), and Hirundo tahitica ( $\mathrm{Di}=5.20)$. The diversity of birds in Ped agroforestry was higher than in Tembeling forest, with $\mathrm{H}^{\prime}=3.82$, and an Evenness Index of 0.88 . Similar to Tembeling forest, in Ped agroforestry, individuals of each bird species were almost evenly distributed, except Hirundo tahitica (Di $=5.99)$ and Streptopelia chinensis $(\mathrm{Di}=5.63)$ which were classified as dominant (Table 1). The Similarity Index (SI) between Tembeling forest and Ped agroforestry based on bird species was 0.93 . This means that the composition of bird species in the two habitats was almost the same.

\section{Profile and diversity of tree vegetation}

Observation of vegetation profile was carried out to determine the function and utilization of habitat for birds. The profile of tree vegetation in Tembeling forest and Ped agroforestry presented in Figure 2. Tree vegetation was slightly denser in Tembeling forest than Ped agroforestry, but canopy cover was denser in Ped agroforestry, it was due to more tree branches.

We found 25 species of trees in Tembeling forest, with a Diversity Index ( $\left.\mathrm{H}^{\prime}\right)$ of 2.62. The dominant species were Swietenia macrophylla with Index of Important Value (IIV) of $389.08 \%$, Azadirachta indica (IIV = 167.61\%), Albizia saman $(\mathrm{IIV}=145.26 \%)$, Tectona grandis $(\mathrm{IIV}=$ $150.37 \%$ ), and Ficus glabella (IIV $=124.06 \%$ ). In Ped agroforestry, there were 22 species of trees with a Diversity Index of 2.69. Ficus glabella was a dominant tree species with IIV of $80.33 \%$, followed by Mangifera indica (IIV= $60.62 \%$ ), Muntingia calabura (IIV = 34.42\%), Albizia saman (IIV $=26.88 \%$ ), and Tectona grandis (IIV = $24.74 \%$ ). The level of similarity between Tembeling forest and Ped agroforestry based on tree species was 0.81 , and indicates that the composition of tree species in the two habitats was almost the same. Table 2 presents the use of trees by birds in these two study sites.

Table 1. Species diversity, dominant species of birds and their conservation status in Tembeling and Ped, Nusa Penida, Bali, Indonesia from January to March 2019

\begin{tabular}{|c|c|c|c|c|c|}
\hline \multirow{2}{*}{ Common name } & \multirow{2}{*}{ Scientific name } & \multicolumn{2}{|c|}{ Dominance (Di) } & \multicolumn{2}{|c|}{ Conservation status } \\
\hline & & Tembeling (\%) & Ped (\%) & Permen & IUCN \\
\hline Javan Myna & Acridotheres javanicus & 1.00 & 0.88 & NP & $\mathrm{LC}$ \\
\hline Common Myna & Acridotheres tertius & 1.40 & 1.23 & $\mathrm{P}$ & $\mathrm{CR}$ \\
\hline Common lora & Aegithina tiphia & 2.60 & 2.99 & NP & $\mathrm{LC}$ \\
\hline White Breasted Waterhen & Amaurornis phoenicurus & 3.80 & 2.64 & NP & $\mathrm{LC}$ \\
\hline Brown Throated Sunbird & Anthreptes malacensis & 0.20 & 0.18 & NP & $\mathrm{LC}$ \\
\hline Little Swift & Apus affinis & 3.40 & 2.11 & NP & $\mathrm{LC}$ \\
\hline Litle Spiderhunter & Arachnothera longirostra & 0.20 & 0.18 & NP & $\mathrm{LC}$ \\
\hline White Breasted Woodswallow & Artamus leucorynchus & 0.60 & 0.53 & NP & $\mathrm{LC}$ \\
\hline Yellow Crested Cockatoo & Cacatua sulphurea & 0.60 & 0.00 & $\mathrm{P}$ & $\mathrm{CR}$ \\
\hline Plaintive Cucko & Cacomantis merulinus & 1.00 & 2.99 & NP & $\mathrm{LC}$ \\
\hline Lesser Coucal & Centropus bengalensis & 0.60 & 0.53 & NP & $\mathrm{LC}$ \\
\hline Common Emerald Dove & Chalcophaps indica & 0.60 & 0.53 & NP & $\mathrm{LC}$ \\
\hline Olive Backed Sunbird & Cinnyris jugularis & 4.80 & 3.35 & NP & $\mathrm{LC}$ \\
\hline Edible Nest Swiftlet & Collocalia fucifaga & 2.60 & 2.64 & NP & $\mathrm{LC}$ \\
\hline
\end{tabular}


Glossy Swiftlet

Black Nest Swiftlet

Oriental Magpie Robin

Large Billed Crow

Asian Palm Swift

Asian House Martin

Fulvous Breasted Woodpecker

Red Chested Flowerpecker

Scarlet headed Flowerpecker

Hair Crested Drongo

Black Drongo

Green Imperial Pigeon

Pied Imperial Pigeon

Pacific Reef Heron

Spotted Kestrel

Christmas Frigatebird

Lesser Frigatebird

Red Junglefowl

Green Junglefowl

Zebra Dove

Golden Bellied Gerygone

Common Hill Myna

White Bellied Sea Eagle

Brahminy Kite

Black Winged Flycatcher Shrike

Barn Swallow

Pacific Swallow

Black Naped Monarch

Black Eagle

White Shouldered Triller

Bali Starling

Indonesian Honeyeater

Long billed Dowitcher

Javan Munia

Black Faced Munia

Scaly Breasted Munia

Mees's White Eye

Chestnut Headed Bee Eater

Blue Tailed Bee Eater

Eurasian Curlew

Whimbrel

Black Naped Oriole

Olive Backed Tailorbird

Mangrove Whistler

Cinereous Tit

Eurasian Tree Sparrow

White Tailed Tropicbird

Mountain Leaf Warbler

Bar Winged Prinia

Black Naped Fruit Dove

Sooty Headed Bulbul

Yellow Vented Bulbul

Malaysian Pied Fantail

Crested Serpent Eagle

Little Tern

Bridled Tern

Island Collared Dove

Spotted Dove

Collared Kingfisher

Sacred Kingfisher

Pink Naped Green Pigeon

Common Sandpiper

Barred Buttonquail

Lemon Bellied White Eye

Mountain White Eye

Oriental White Eye
Collocalia esculenta

Collocalia maxima

Copsychus saularis

Corvus macrorhynchos

Cypsiurus balasiensis

Delichon dasypus

Dendrocopus macei

Dicaeum maugei

Dicaeum trochileum

Dicrurus hottentottus

Dicrurus macrocercus

Ducula aenea

Ducula bicolor

Egretta sacra

Falco moluccensis

Fregata andrewsi*

Fregata ariel*

Gallus gallus

Gallus varius

Geopelia striata

Gerygone sulphurea

Gracula religiosa

Haliaeetus leucogaster

Haliastur indus

Hemipus hirundinaceus

Hirundo rustica*

Hirundo tahitica

Hypothymis azurea

Ictinaetus malaiensis

Lalage sueurii

Leucopsar rothschildi

Lichmera limbata

Limnodromus scolopaceus*

Lonchura leucogastroides

Lonchura molucca

Lonchura punctulata

Lophozosterops javanicus

Merops leschenaultii

Merops philippinus

Numenius arquata*

Numenius phaeopus*

Oriolus chinensis

Orthotomus sepium

Pachycephala grisola

Parus major

Passer montanus

Phaethon lepturus

Phylloscopus trivirgatus

Prinia familiaris

Ptilinopus melanospila

Pycnonotus aurigaster

Pycnonotus goiavier

Rhipidura javanica

Spilornis cheela

Sterna albifrons*

Sterna anaethetus*

Streptopelia bitorquata

Streptopelia chinensis

Todiramphus chloris

Todirhampus sanctus

Treron vernans

Tringa hypoleucos

Turnix suscitator

Zosterops chloris

Zosterops montanus

Zosterops palpebrosus
3.80

2.29

1.94

0.88

1.23

1.23

0.18

0.70

1.58

1.06

0.35

1.23

2.82

0.53

0.18

0.18

0.18

0.18

0.35

0.70

2.82

0.18

0.18

0.35

0.35

1.06

4.05

5.99

0.35

0.18

1.58

4.23

0.53

0.18

1.06

0.18

3.17

0.18

2.99

4.05

0.18

0.18

0.88

0.18

0.18

2.46

0.18

0.18

0.18

0.18

1.06

3.35

4.05

1.58

0.35

0.18

0.18

2.46

5.63

2.11

0.35

0.88

0.18

0.18

0.18

0.18

0.18
NP

NP

NP

NP

NP

NP

NP

NP

NP

NP

NP

NP

NP

NP

$\mathrm{P}$

P

NP

NP

NP

NP

$\mathrm{P}$

$\mathrm{P}$
$\mathrm{P}$

P

NP

NP

P

NP

$\mathrm{P}$

NP

$\mathrm{P}$
$\mathrm{NP}$

NP

NP

NP

NP

NP

$\mathrm{P}$
$\mathrm{P}$

$\mathrm{P}$
NP

NP

NP

NP

NP

P

NP

NP

NP

NP

NP

NP

P

NP

NP

NP

NP

NP

NP

NP

NP

NP

NP

NP

LC

$$
\text { LC }
$$

LC

$$
\text { LC }
$$

LC

LC

LC

LC

LC

LC

LC

$\mathrm{LC}$
$\mathrm{LC}$

LC

CR

LC

LC

LC

LC

LC

LC

LC

LC

LC

LC

LC

LC 

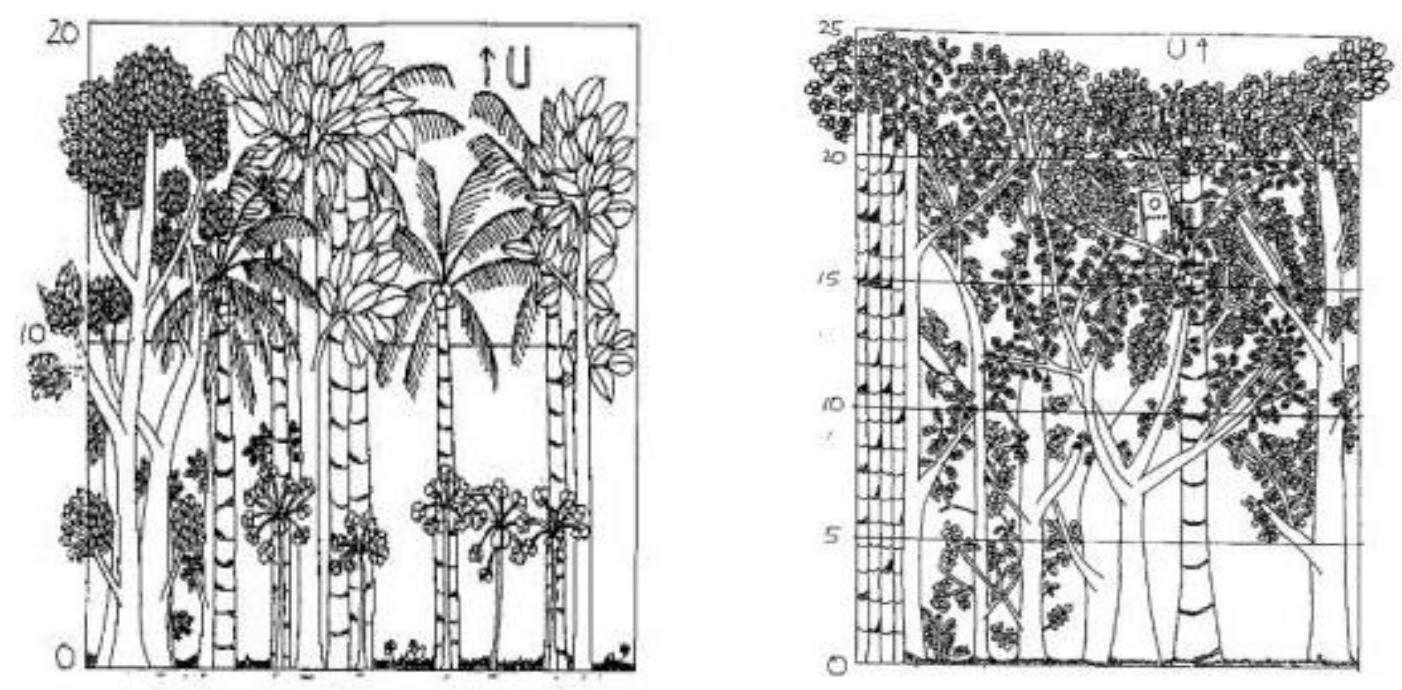

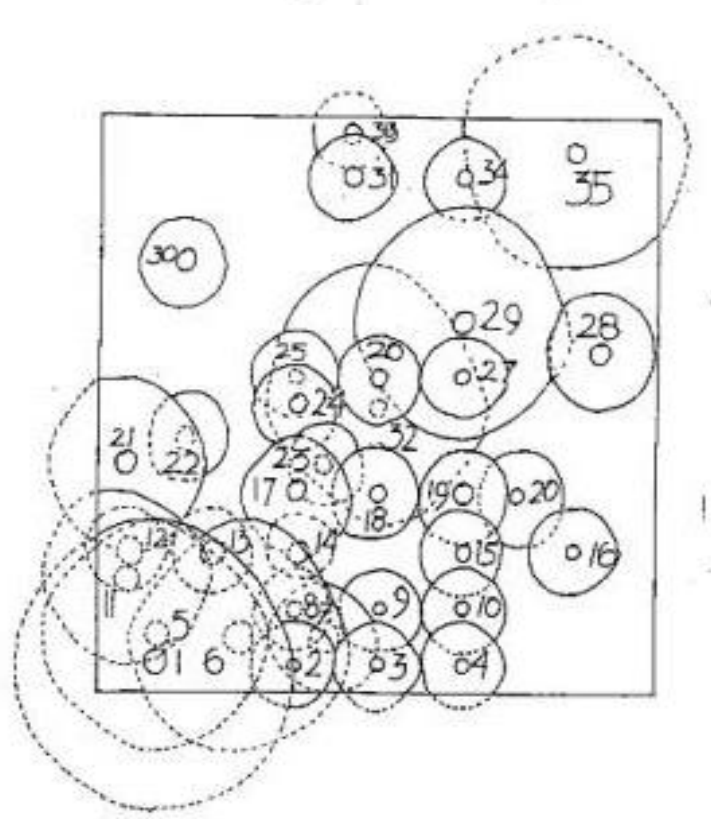

A

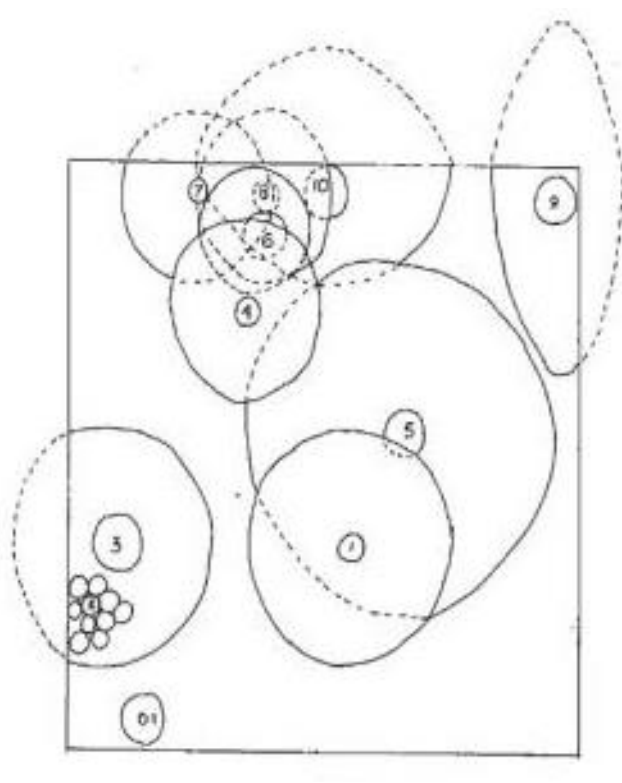

B

Figure 2. Tree vegetation profile in: A) Tembeling forest: Ficus glabella (1, 15, 11, 12, 21), Mutingia calabura (8-10, 14-16); Cocos nucifera (6, 31); Tectona grandis (7, 28); Gliricidia sepium (13, 22); Mangifera indica (23, 24); B) Ped agroforestry: Albizia saman (13); Dendrocalamus asper (2); Ficus glabella (4, 8, 9); Cocos nucifera (5); Sysygium aqueum (6); Swietenia macrophylla (7); Ficus rumphii (10); Ziziphus mauritinia (11).

\section{Discussion}

The diversity of bird species in Ped agroforestry and Tembeling forest was high. In general, the abundance and diversity of birds were directly related to the condition of their habitat (Partasasmita et al. 2017; Krisanti et al. 2017). This means that Tembeling forest and Ped agroforestry can support the lives of birds for foraging, resting, and nesting. Almost all (93\%) the tree species found in both habitats provide a source of food for the birds.

Ficus glabella was most widely used by birds, among other trees. Trees that can provide the resources needed by various bird species, enable each stratum of the canopy to be used by certain bird species (Rahayuningsih and
Nugroho 2013; Partasasmita et al. 2017). Ficus glabella produces fruit that is a source of food for birds, and has many branches that make it a good place for resting and nesting. Leucopsar rothschildi, Acridotheres tertius, and Acridotheres javanicus often used Ficus glabella for food, resting, and nesting. Other trees also widely used by birds were Ficus benjamina, Albizia saman, and Muntingia calabura. In addition to these trees, shrubs and herbs that produce nectar, fruits and seeds, such as Datura metel, Lantana camara, Temeda arguens, Hoplismenus sp., Axonopus sp., Eragrostis sp., Kylinga monocepala, and Chloris barbata were also sources of food for Bali Starling in Ped agroforestry (Ginantra et al. 2009). 
Table 2. Tree vegetation utilization and function for birds in Tembeling forest and Ped agroforestry, Nusa Penida, Bali, Indonesia from January to March 2019

\begin{tabular}{|c|c|c|c|c|}
\hline \multirow{2}{*}{ Common name } & \multirow{2}{*}{ Scientific name } & \multicolumn{2}{|c|}{ Utilization } & \multirow{2}{*}{ Function } \\
\hline & & Tembeling (\%) & Ped $(\%)$ & \\
\hline Earleaf acacia & Acacia auriculiformis & 5.71 & 0 & $\mathrm{R}, \mathrm{F}$ \\
\hline Rain tree & Albizia saman & 18.57 & 13.92 & $\mathrm{R}, \mathrm{F}$ \\
\hline Soursop & Annona muricata & 0 & 11.39 & $\mathrm{R}, \mathrm{F}$ \\
\hline Queensland-cherry & Antides mabunius & 12.86 & 20.25 & $\mathrm{~F}$ \\
\hline Jackfruit & Artocarpus heterophyllus & 8.57 & 16.46 & $\mathrm{R}, \mathrm{F}, \mathrm{N}$ \\
\hline Neem & Azadirachtaindica & 10.00 & 11.39 & $\mathrm{R}, \mathrm{F}$ \\
\hline Cananga tree & Cananga odorata & 7.14 & 13.92 & $\mathrm{R}, \mathrm{F}$ \\
\hline Coconut tree & Cocos nucifera & 5.71 & 8.86 & $\mathrm{R}$ \\
\hline Giant bamboo & Dendrocalamus asper & 2.86 & 2.53 & $\mathrm{R}$ \\
\hline Ficus tree & Ficus benjamina & 24.29 & 30.38 & $\mathrm{R}, \mathrm{F}, \mathrm{N}$ \\
\hline White fig & Ficus glabella & 38.57 & 45.57 & $\mathrm{R}, \mathrm{F}, \mathrm{N}$ \\
\hline Jackson fig & Ficus rumphii & 2.86 & 7.59 & $\mathrm{R}, \mathrm{F}, \mathrm{N}$ \\
\hline Indian plum & Flacourtia rukam & 2.86 & 0 & $\mathrm{R}, \mathrm{F}$ \\
\hline Quickstick & Gliricidia sepium & 10.00 & 17.72 & $\mathrm{R}, \mathrm{F}$ \\
\hline Beechwood & Gmelina arborea & 2.86 & 2.53 & $\mathrm{R}, \mathrm{F}$ \\
\hline Giant crepe-myrtle & Lagerstroemia speciosa & 8.57 & 0 & $\mathrm{R}, \mathrm{F}$ \\
\hline Indian ash tree & Lannea grandis & 10.00 & 0 & $\mathrm{R}, \mathrm{F}$ \\
\hline Mango & Mangifera indica & 5.71 & 11.39 & $\mathrm{R}, \mathrm{F}, \mathrm{N}$ \\
\hline Indian mulberry & Morinda citrifolia & 4.29 & 10.13 & $\mathrm{R}, \mathrm{F}$ \\
\hline Kerson fruit & Muntingia calabura & 5.71 & 20.25 & $\mathrm{R}, \mathrm{F}$ \\
\hline Indian sandalwood & Santalum album & 0 & 2.53 & $\mathrm{R}, \mathrm{F}$ \\
\hline Walik ukun & Schoutenia ovata & 5.71 & 0 & $\mathrm{R}, \mathrm{F}$ \\
\hline African tulip tree & Spathodea campanulata & 0 & 5.06 & $\mathrm{R}, \mathrm{F}$ \\
\hline Mahogany & Swietenia macrophylla & 8.57 & 16.46 & $\mathrm{R}, \mathrm{F}$ \\
\hline Watery rose apple & Syzygium аqиеит & 0 & 2.53 & $\mathrm{R}, \mathrm{F}$ \\
\hline Tamarind & Tamarindus indica & 5.71 & 0 & $\mathrm{R}, \mathrm{F}$ \\
\hline Teak & Tectona grandis & 5.71 & 8.86 & $\mathrm{R}, \mathrm{F}$ \\
\hline Chinese mahogany & Toona sinensis & 4.29 & 0 & $\mathrm{R}, \mathrm{F}, \mathrm{N}$ \\
\hline Jujube & Ziziphus mauritiana & 2.86 & 3.79 & $\mathrm{R}, \mathrm{F}$ \\
\hline
\end{tabular}

Abbreviations: $\mathrm{R}$ = resting, $\mathrm{F}$ = foraging, $\mathrm{N}$ = nesting

Similarity of bird communities in Ped agroforestry with those in Tembeling forest was high $(93 \%)$. The only difference lies in the presence of shorebirds, given that Ped's agroforestry is located near flat beaches with large tidal areas. On the other hand, Tembeling forest is located on a higher place with steep beaches and big waves, so that no shorebirds were found in this area. The shorebirds such as Limnodromus scolopaceus, Numenius arquata, Numenius phaeopus, Sterna albifrons, Sterna anaethetus, Fregata ariel, Fregata andrewsi, and Hirundo rustica are generally seasonal migratory birds. These birds usually use tidal areas for foraging. The presence of migratory birds on Nusa Penida adds to the importance of the island as a bird conservation area.

During the study, Yellow-crested Cockatoo Cacatua sulphurea was found only in Tembeling forest, which is protected by Permen LHK Republic of Indonesia Number P.106/MENLHK/SETJEN/KUM.1/12/2018 of 2018 and categorized as Critically Endangered by IUCN Red List of Threatened Species. Cacatua sulphurea is endemic to Indonesia, the sub-species C. s. parvula is distributed from Nusa Penida eastwards through the Lesser Sunda chain of islands from Lombok to Alor, and Timor (Setiawan 1996). The existence of this bird in Tembeling forest is due to the presence of large trees with height between 10 to $25 \mathrm{~m}$, which are used for nesting. The big trees, among others, were: Swietenia macrophyllus, Ficus glabella and Toona sinensis. During the survey in Nusa Penida, Setiawan (1996) noted 27 species of trees for foraging and nesting of this bird, including Sterculia foetida, Ceiba petandra, Tamarindus indica, and Cocos nucifera. In Komodo National Park, Imansyah et al. (2005) reported that this bird used large and tall trees between 7 to $20 \mathrm{~m}$ for nesting, such as Sterculia oblongata, Corypha utan, and Borassus flabellifer.

Twenty four Bali Starling Leucopsar rothschildii were found in Ped agroforestry. The bird is protected by Permen LHK Republic of Indonesia Number P.106/MENLHK/SETJEN/KUM.1/12/2018 of 2018, and listed in the Critically Endangered category by IUCN Red List of Threatened Species. Bali Starling was present in Ped agroforestry after it was released by the Friends of National Park Foundation in 2005 (Sudaryanto et al. 2018). Gracula religiosa was also found in Ped agroforestry. This bird is protected by Permen LHK Republic of Indonesia Number P.106/MENLHK/SETJEN/KUM.1/12/2018 of 2018 and categorized as Least Concern by IUCN Red List of Threatened Species. It is suspected that the bird escaped from its owner's cage, because its natural distribution only reached Bali Island (MacKinnon et al. 2010; Mason 2011). 
All villages in Nusa Penida own and implement awigawig that protect birds. For example, awig-awig of Ped Village (Suklaa 1987), regulates the prohibition of bird hunting, especially Bali Starling. One of the sanctions in awig-awig is paying financial fines and social sanctions for people who catch, sell, and shoot birds. This also applies to migrants who are not Hindus. Although in Nusa Penida there is an Islamic Village, namely Toyapakeh, which does not have awig-awig, their residents also obey the awigawig of surrounding villages. Until now, there have never been residents who violated this awig-awig (Wirayudha 2007; Sudaryanto et al. 2019). The existence of awig-awig that protects all animals, especially birds, ensures the conservation of birds in Nusa Penida to be successful (Sudaryanto et al. 2019). Since formal law often fails to prevent bird hunting, awig-awig has a strategic position to conserve birds in Nusa Penida. The high diversity of birds, as well as the unique local communities in protecting birds enable Nusa Penida to be developed as a birdwatching ecotourism area.

To conclude, in Nusa Penida, there were 80 species of birds, consisting of 70 species in Tembeling forest and 79 species in Ped agroforestry. Some of these birds are protected under Permen LHK Republic of Indonesia Number P.106/MENLHK/SETJEN/KUM.1/12/2018 of 2018, and have Near Threatened and Critically Endangered status according to IUCN Red List of Threatened Species. The habitat in Nusa Penida is very supportive of birdlife because it can provide resources for birds for foraging, resting, and nesting. The presence of migratory birds, the conservation status, and the unique local custom to protect birds are strong reasons to propose Nusa Penida as a bird conservation area and for birdwatching ecotourism in the future.

\section{ACKNOWLEDGEMENTS}

We thank Professor Yong Hoi Sen for helpful advice and discussion. Our gratitude to the Department of Biology, Faculty of Mathematics and Natural Sciences, University of Udayana, Bali, Indonesia and Department of Biology, Faculty of Mathematics and Natural Sciences, University of Mataram, Indonesia for facilitating this collaborative research.

\section{REFERENCES}

Agustina R. 2013. Community-based Bali Myna Ecotourism Development Strategy in Nusa Penida Island, Klungkung Regency. Udayana University, Denpasar. [Indonesian]

Barbour MG, Burk JH, Pitts WD. 1987. Terrestrial Plant Ecology. The Benjamin/Cumming Publising Company, Inc. California.

Bibby C, Jones M, Marsden S. 2000. Field Expedition Techniques: Bird Surveys. Birdlife International-Indonesia Program, Bogor. [Indonesian]

Dewi RK, Mulyani Y, Santosa Y. 2007. Diversity of bird species at some habitat type in Ciremai Mountain National Park. Media Konservasi 12 (3): 114-118. [Indonesian]

English S, Wilkinson C, Baker V. 1994. Survey Manual for Tropical Marine Resource. Australian Institute of Marine Science, Townsville, Australia.
Ginantra IK, Dalem AAGR, Sudirga SK, Wirayudha IGNB. 2009. Species of plants as a source of Bali Starling feed (Leucopsar rothschildi S) in Ped Village, Nusa Penida, Klungkung, Bali. J Bumi Lestari 9 (1): 91 102. [Indonesian]

Hermawan B, Prasetyo RB, Yanwar Y, Negara HK, Iqbal M. 2013. First record and breeding of Greater painted Snipe in Bali, Indonesia. Stilt 63-64: 27-28

Imansyah MJ, Anggoro DG, Hidayat A, Yangpatra N, Benu YJ. 2005. Distribution and characteristics of the yellow-crested small cockatoo nest tree (Cacatua sulphurea parvula) on Komodo Island, Komodo National Park. Report No. 4. CRES Komodo Project-Komodo National Park. Denpasar. [Indonesian]

International Union for Conservation of Nature and Natural Resources Red List of Threatened Species (IUCN). https://www.iucnredlist.org/

Klungkung Regency Government (Pemkab Klungkung). 2013. Klungkung in $\quad$ Figures 2012 Geographical Conditions. http://www.klungkungkab.go.id [Indonesian]

Krisanti AA, Choirunnafi A, Septiana NO, Pratama FW, Amelia F, Manjaswari A, Septiningtyas PA, Wati, AS, Satria JY, Ani IL, Wibowo T, Sugiyarto. 2017. The diversity of diurnal bird species on western slope of Mount Lawu, Java, Indonesia. Biodiversitas 18(3): 1077-1083. DOI: 10.13057/biodiv/d180327

Ludwig JA, Reynolds JF. 1988. Statistical Ecology: A Primer in Methods and Computing. John Wiley \& Sons, New York.

MacKinnon J, Phillipps K, van Balen B. 2010. Birds of Sumatra, Java, Bali and Kalimantan (including Sabah, Sarawak and Brunei Darussalam). Puslitbang Biologi LIPI \& Burung Indonesia, Bogor. [Indonesian]

Magurran AE. 1988. Ecological Diversity and Its Measurement. Princeton University Press, New Jersey.

Martin P, Bateson P. 2006. Measuring Behavior: An Introductory Guide. Cambridge University Press, Cambridge.

Mason V, Jarvis F. 1994. Birds of Bali. Periplus Editions, Singapore.

Mason V. 2011. A revised checklist for the birds of Bali, with notes on recent additions to the avifauna. Kukila 15: 1-30.

Partasasmita R, Atsaury ZIA, Husodo T. 2017. The use of forest canopy by various bird species in tropical forest montana zone, the Nature Reserve of Mount Tilu, West Java, Indonesia. Biodiversitas 18(2): 453-457. DOI: 10.13057/biodiv/d180202

Paskal S, Winarsih A, Wijayanti F. 2015. Bird community in Tidung Kecil Islands, Seribu Islands. Al-Kauniyah J Biol 8(2): 66-76. DOI: 10.15408/kauniyah.v8i2.2692 [Indonesian]

Permen LHK. Regulation of the Minister of Environment and Forestry of the Republic of Indonesia Number P.106/MENLHK/SETJEN/KUM.1/12/2018 of 2018 Concerning Species of Plants and Animals Protected. [Indonesian].

Rahayuningsih M, Nugroho EK. 2013. The distribution and population of Wreathed Hornbill (Aceros udulatus) in Mount Ungaran Central Java. Int J Environ Sci Develop 4 (5): 493-495. DOI: 10.7763/IJESD.2013.V4.401

Riany CF, Aunurohim. 2013. Bali Myna (Leucopsar rothschildi Stresemann, 1912) Population and release in Ped agroforestry and Tembeling forest. J Sains Seni 2 (2): 186-190. [Indonesian]

Setiadi D. 2004. The diversity of trees species in Taman Wisata Alam Ruteng, East Nusa Tenggara. Biodiversitas 6 (2): 118-122. DOI: 10.13057/biodiv/d060210 [Indonesian]

Setiawan I. 1996. The status of sulphur-crested cockatoo (Cacatua sulphurea parvula) on Nusa Penida, Bali and Sumbawa, West Nusa Tenggara. Laporan No. 6, 1996. PHPA/BirdLife InternationalIndonesia Programme, Bogor.

Sudaryanto FX, Djohan TS, Pudyatmoko S, Subagja J. 2015. Behaviour of Bali Starling at Bali Barat National Park and Nusa Penida Island. J Veteriner 16 (3): 364-370.

Sudaryanto FX, Pudyatmoko S, Subagja J, Djohan TS. 2019. The role of awig-awig of traditional village to Bali Starling conservation in Nusa Penida Islands. J Kajian Bali 9 (1): 227-240. DOI: 10.24843/JKB.2019.v09.i01.p11 [Indonesian]

Sudaryanto FX, Subagja J, Pudyatmoko S, Djohan TS. 2018. Distribution of Bali Starling in Nusa Penida Island. Simbiosis 6(2): 40-44. DOI: 10.24843/JSIMBIOSIS.2018.v06.i02.p02 [Indonesian]

Sudiarkajaya IM, Utama MS, Yasa INM, Yuliarmi NN. 2018. Tourism development strategy in Nusa Penida District Klungkung Regency, Bali Province, Indonesia. Intl J Econ Commerce Manag 6 (8): 130143.

Suklaa IW. 1987. Awig-awig of Ped Village. Nusa Penida District. Klungkung Regency. [Indonesian] 
van Noordwijk M, Agus F, Suprayogo D, Hiriah K, Pasya G, Verbist B, Farida. 2004. Role of agroforestry in maintenance of hydrological functions in water catchment areas. Agrivita 26 (1): 1-8. [Indonesian]

Wirayudha IGNB. 2007. Release and Rescue of Bali Starlings in Nusa Penida. FNPF, Ubud, Bali. [Indonesian]
Wirayudha IGNB. 2008. Annual Report. FNPF, Ubud, Bali. [Indonesian] Wulandari C. 2009. Identification of agroforestry patterns that applied by the community at marginal land in North Lampung. J Ilmu Pertanian Indonesia 14(3): 158-162. [Indonesian] 